\title{
Polaromonas jejuensis sp. nov., isolated from soil in Korea
}

\section{Correspondence \\ Soon-Wo Kwon \\ swkwon@rda.go.kr}

\section{Hang-Yeon Weon, ${ }^{1}$ Seung-Hee Yoo, ${ }^{2}$ Seung-Beom Hong, ${ }^{2}$ Soon-Wo Kwon, ${ }^{2}$ Erko Stackebrandt, ${ }^{3}$ Seung-Joo Go ${ }^{2}$ and Bon-Sung Koo ${ }^{2}$}

\footnotetext{
${ }^{1}$ Applied Microbiology Division, National Institute of Agricultural Science and Technology, Rural Development Administration, Suwon 441-707, Republic of Korea

${ }^{2}$ Korean Agricultural Culture Collection (KACC), Microbial Genetics Division, National Institute of Agricultural Biotechnology, Rural Development Administration, Suwon 441-707, Republic of Korea

${ }^{3} \mathrm{DSMZ}$ - Deutsche Sammlung von Mikroorganismen und Zellkulturen GmbH, Inhoffenstraße 7b, D-38124 Braunschweig, Germany
}

The genus Polaromonas was first proposed by Irgens et al. (1996) for a psychrophilic, marine bacterium isolated from Antarctica, Polaromonas vacuolata. Since then, three more species with validly published names have been included: Polaromonas naphthalenivorans, from freshwater sediment (Jeon et al., 2004), Polaromonas aquatica, isolated from tap water (Kämpfer et al., 2006), and Polaromonas hydrogenivorans, from Alaskan soil (Sizova \& Panikov, 2007). In this work, a polyphasic taxonomic approach was used to characterize a bacterial strain, JS12-13 ${ }^{\mathrm{T}}$, isolated from a soil sample from Halla Mountain on Jeju Island, Republic of Korea; this strain was found to represent a novel species of the genus Polaromonas.

For the isolation of strain JS12-13 ${ }^{\mathrm{T}}$, a $1 \mathrm{~g}$ soil sample was suspended in $9 \mathrm{ml} 0.85 \% \mathrm{NaCl}(\mathrm{w} / \mathrm{v})$ and mixed in a shaker for $30 \mathrm{~min}$. After serial dilution, aliquots of the serial diluents were spread on R2A agar plates (Reasoner \& Geldreich, 1985) and incubated at $28{ }^{\circ} \mathrm{C}$ for 5 days. Isolate JS12-13 ${ }^{\mathrm{T}}$ was cultured routinely and maintained on R2A agar at $28{ }^{\circ} \mathrm{C}$. It also grew on nutrient agar (Difco). However, no growth was observed on tryptic soy agar (Difco) and MacConkey agar (Difco).

\footnotetext{
The GenBank/EMBL/DDBJ accession number for the 16S rRNA gene sequence of strain $J S 12-13^{\top}$ is EU030285.
}

Gram staining and catalase and oxidase determinations and tests for the hydrolysis of casein, DNA, starch and Tween 80 were conducted according to the methods of Smibert \& Krieg (1994). The hydrolysis of CM-cellulose (Sigma) $(0.1 \%)$, chitin $(1 \%, \mathrm{w} / \mathrm{v})$, hypoxanthine $(0.5 \%$, w/v), pectin $(0.5 \%, \mathrm{w} / \mathrm{v})$, tyrosine $(0.5 \%, \mathrm{w} / \mathrm{v})$ and xanthine $(0.5 \%, \mathrm{w} / \mathrm{v})$ was also tested. Cell morphology was observed by means of transmission electron microscopy (model 912AB; LEO) and phase-contrast microscopy (AXIO; Zeiss), using cells grown for 2 days at $28{ }^{\circ} \mathrm{C}$ on $\mathrm{R} 2 \mathrm{~A}$. Anaerobic growth was tested on R2A incubated in an anaerobic jar (BBL). Growth at different temperatures (5, $15,20,25,30,35$ and $40{ }^{\circ} \mathrm{C}$ ) and various $\mathrm{pH}$ values ( $\mathrm{pH} 4.0-10.0$, in increments of $1.0 \mathrm{pH}$ units) was assessed after 14 days incubation on R2A. Salt tolerance was tested on R2A agar supplemented with $0-5 \%(w / v) ~ N a C l$. Other physiological and biochemical properties, including carbon-source utilization patterns and enzyme activities, were tested by using the API 20NE, API ID 32GN and API ZYM test kits (bioMérieux).

The 16S rRNA gene was amplified by using a PCR with two universal primers, as described previously (Kwon et al., 2003). The sequence of the amplified 16S rRNA gene was analysed using an Applied Biosystems DNA sequencer (ABI3100). 16S rRNA gene sequences were aligned using CLUSTAL W software (Thompson et al., 1994). Nucleotide 
similarity values were calculated from the alignment. Phylogenetic trees for the datasets were inferred from neighbour-joining (Saitou \& Nei, 1987) and maximumparsimony (Fitch, 1971) analyses using MEGA, version 3.0 (Kumar et al., 2004). The stability of relationships was assessed by performing bootstrap analyses based on 1000 resamplings.

DNA-DNA hybridization was carried out using the filter hybridization method described by Seldin \& Dubnau (1985). Probe labelling was conducted by using the nonradioactive DIG-High prime system (Roche); hybridized DNA was visualized using the DIG luminescent detection kit (Roche). DNA-DNA relatedness was quantified by using a densitometer (Bio-Rad). Chemotaxonomic characteristics were determined using cells grown at $28{ }^{\circ} \mathrm{C}$ for 3 days on R2A. Isoprenoid quinones were analysed using HPLC (Shimadzu) as described by Groth et al. (1996). The DNA $\mathrm{G}+\mathrm{C}$ content $(\mathrm{mol} \%)$ was determined by HPLC analysis of deoxyribonucleosides, as described by Mesbah et al. (1989), using a reversed-phase column (Supelcosil
LC-18 S; Supelco). Analysis of the fatty acid methyl esters was performed using GLC according to the instructions of the Microbial Identification System (MIDI).

Cells of strain JS12-13 ${ }^{\mathrm{T}}$ were aerobic, Gram-negative, nonmotile, non-spore-forming rods that were $0.6 \mu \mathrm{m}$ wide and 1-3 $\mu \mathrm{m}$ long. Colonies on R2A agar were pale yellow, circular and convex with entire margins. The differential phenotypic properties for JS12-13 ${ }^{\mathrm{T}}$ and recognized Polaromonas species are shown in Table 1.

Strain JS12-13 ${ }^{\mathrm{T}}$ showed sequence similarities of 96.9$98.4 \%$ with respect to $P$. aquatica CIP $108776^{\mathrm{T}}$ (98.4\%), $P$. hydrogenivorans DSM $17735^{\mathrm{T}}$ (97.8\%), P. naphthalenivorans DSM $15660^{\mathrm{T}}(97.6 \%)$ and P. vacuolata $34-\mathrm{P}^{\mathrm{T}}(96.8 \%)$. Strain JS12-13 ${ }^{\mathrm{T}}$ showed less than $97 \%$ 16S rRNA gene sequence similarity with respect to the type strains of other species. In the neighbour-joining phylogenetic tree, strain JS12-13 ${ }^{\mathrm{T}}$ formed a robust cluster with members of the genus Polaromonas, with $100 \%$ bootstrap support (Fig. 1). The maximum-parsimony phylogenetic tree also supported

Table 1. Differential phenotypic characteristics of strain $\mathrm{JS} 12-13^{\top}$ and type strains of recognized Polaromonas species

Strains: 1, JS12-13 ${ }^{\mathrm{T}}$; 2, P. aquatica CIP $108776^{\mathrm{T}}$ (unless indicated, data from Kämpfer et al., 2006); 3, P. hydrogenivorans DSM $17735^{\mathrm{T}}$ (Sizova \& Panikov, 2007); 4, P. naphthalenivorans DSM $15660^{\mathrm{T}}$ (Jeon et al., 2004); 5, P. vacuolata 34- $\mathrm{P}^{\mathrm{T}}$ (Irgens et al., 1996). Assimilation data for all strains except $P$. vacuolata $34-\mathrm{P}^{\mathrm{T}}$ were obtained using API $20 \mathrm{NE}$ and API ID $32 \mathrm{GN}$ test strips in this study. All of the strains are positive for catalase and oxidase and all are negative for nitrate reduction, indole production and glucose fermentation. +, Positive; - , negative; ND, no data available.

\begin{tabular}{|c|c|c|c|c|c|}
\hline Characteristic & 1 & 2 & 3 & 4 & 5 \\
\hline Isolation source & Soil & Tap water & Soil & Freshwater sediment & Seawater \\
\hline Cell shape & Rods & Rods & Cocci & Cocci & Rods \\
\hline Cell size (width $\times$ length; $\mu \mathrm{m}$ ) & $0.6 \times 1-3$ & $\mathrm{ND} \times 1-2$ & $0.8-2.8$ & $1-4$ & $0.8 \times 2-3$ \\
\hline Motility & - & + & - & - & + \\
\hline Growth temperature $\left({ }^{\circ} \mathrm{C}\right)$ & $5-30$ & $\mathrm{ND}$ & $0-25$ & $4-25$ & $0-12$ \\
\hline Growth at $30{ }^{\circ} \mathrm{C}$ & + & + & - & - & - \\
\hline Urease & - & $-{ }^{*}$ & $-{ }^{*}$ & $-*$ & + \\
\hline$\beta$-Galactosidase & + & $-*$ & $-*$ & $-*$ & ND \\
\hline \multicolumn{6}{|l|}{ Assimilation of: } \\
\hline D-Glucose & - & - & + & - & + \\
\hline Potassium gluconate & + & + & + & - & $\mathrm{ND}$ \\
\hline Malic acid & + & + & - & - & + \\
\hline Trisodium citrate & + & - & - & - & + \\
\hline Itaconic acid & + & - & - & - & ND \\
\hline Suberic acid & + & + & - & - & ND \\
\hline Lactic acid & + & + & - & - & + \\
\hline L-Alanine & + & + & + & - & + \\
\hline Glycogen & - & - & - & + & $\mathrm{ND}$ \\
\hline 3-Hydroxybenzoic acid & - & + & - & - & $\mathrm{ND}$ \\
\hline L-Serine & - & - & + & - & - \\
\hline D-Sorbitol & - & - & - & - & + \\
\hline Propionic acid & + & - & - & - & + \\
\hline L-Histidine & + & - & - & - & - \\
\hline 3-Hydroxybutyric acid & + & + & - & - & + \\
\hline 4-Hydroxybenzoic acid & - & + & - & - & $\mathrm{ND}$ \\
\hline L-Proline & + & + & + & - & + \\
\hline DNA G $+\mathrm{C}$ content $(\mathrm{mol} \%)$ & 63.7 & $\mathrm{ND}$ & 62.5 & 61.5 & 52 \\
\hline
\end{tabular}

${ }^{\star}$ Data from this study. 


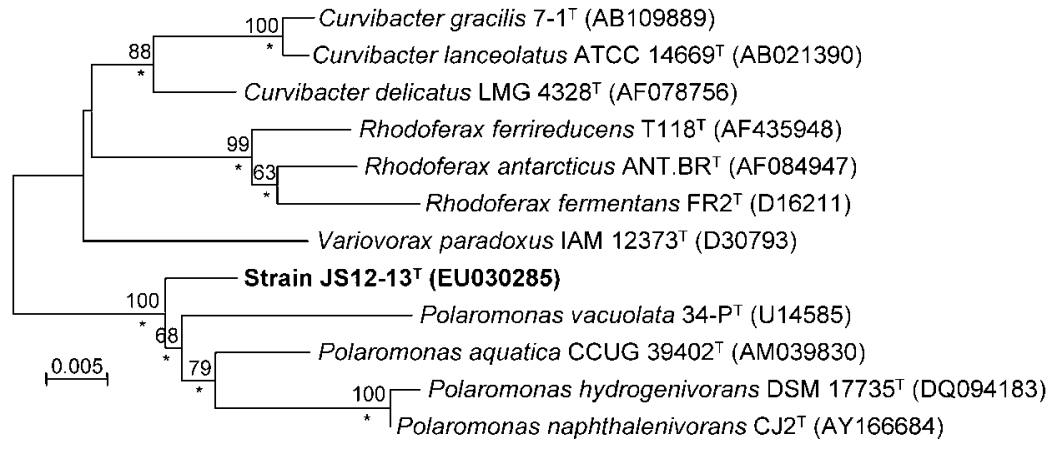

Fig. 1. Neighbour-joining phylogenetic tree based on 16S rRNA gene sequences showing the position of strain JS12-13 ${ }^{\top}$ within the genus Polaromonas. Asterisks indicate branches replicated with maximum-parsimony tree-making algorithms. Numbers at nodes indicate bootstrap percentages (based on 1000 resampled datasets); values below $50 \%$ are not shown. Bar, 0.005 substitutions per site. the inclusion of strain JS12-13 ${ }^{\mathrm{T}}$ as a member of the genus Polaromonas (Fig. 1).

DNA-DNA hybridization tests between strain JS12-13 ${ }^{\mathrm{T}}$ and $P$. aquatica CIP $108776^{\mathrm{T}}$, P. hydrogenivorans DSM $17735^{\mathrm{T}}$ and $P$. naphthalenivorans DSM $15660^{\mathrm{T}}$ revealed values of 43,34 and $28 \%$, respectively. These values are below the threshold (70\%) suggested for species delineation (Stackebrandt \& Goebel, 1994), indicating that strain $\mathrm{JS} 12-13^{\mathrm{T}}$ represents a novel species.

Strain JS12-13 ${ }^{\mathrm{T}}$ contained summed feature 3 (comprising $\mathrm{C}_{16: 1} \omega 7 c$ and/or iso- $\left.\mathrm{C}_{15: 0} 2-\mathrm{OH} ; 38.3 \%\right), \mathrm{C}_{16: 0}(28.4 \%)$, $\mathrm{C}_{17: 0}$ cyclo $(15.9 \%)$ and $\mathrm{C}_{18: 1} \omega 7 c(9.1 \%)$ as the major fatty acids. The fatty acid data (Table 2) were a little different from those of Kämpfer et al. (2006), perhaps because of differences in cultivation method and growth medium. The major quinone found in strain JS12-13 ${ }^{\mathrm{T}}$ was ubiquinone- 8 . The $\mathrm{G}+\mathrm{C}$ content of the genomic DNA of strain JS12-13 ${ }^{\mathrm{T}}$ was $63.7 \mathrm{~mol} \%$.

Phenotypically, the unique characteristics of strain JS12$13^{\mathrm{T}}$ included the presence of $\beta$-galactosidase activity, the assimilation of itaconic acid and L-histidine and the presence of fatty acid $\mathrm{C}_{12: 0}(2.9 \%)$ (Tables 1 and 2$)$. The fatty acid composition of JS12-13 ${ }^{\mathrm{T}}$ was similar to that of $P$. aquatica CIP $108776^{\mathrm{T}}$ (Table 2). However, strain JS12-13 could be differentiated from $P$. aquatica CIP $108776^{\mathrm{T}}$ on the basis of the former's lack of motility and from the substrate-assimilation patterns. The genetic and phenotypic data presented above show that strain JS12-13 ${ }^{\mathrm{T}}$ represents a novel species of the genus Polaromonas, for which the name Polaromonas jejuensis sp. nov. is proposed.

\section{Description of Polaromonas jejuensis sp. nov.}

Polaromonas jejuensis (je.ju.en'sis. N.L. fem. adj. jejuensis referring to Jeju, Korea).

Cells are aerobic, Gram-negative, non-motile, non-sporeforming rods, $0.6 \mu \mathrm{m}$ wide and 1-3 $\mu \mathrm{m}$ long. Colonies on R2A agar are pale yellow, circular and convex with entire margins. Growth occurs at 5-30 ${ }^{\circ} \mathrm{C}$ (optimum, $28-30{ }^{\circ} \mathrm{C}$ ), pH 5-9 (optimum, pH 6-7) and 0-1\% NaCl. Hydrolyses hypoxanthine, tyrosine and xanthine, but not casein, chitin, CM-cellulose, DNA, pectin, starch or Tween 80.
Assimilates potassium gluconate, malic acid, trisodium citrate, itaconic acid, suberic acid, lactic acid, L-alanine, propionic acid, L-histidine, 3-hydroxybutyric acid and L-proline, but not D-glucose, L-arabinose, D-mannose, D-mannitol, $N$-acetylglucosamine, maltose, capric acid, adipic acid, phenylacetic acid, L-rhamnose, D-ribose, inositol, sucrose, sodium malonate, sodium acetate, potassium 5-ketogluconate, glycogen, 3-hydroxybenzoic acid, L-serine, salicin, melibiose, L-fucose, D-sorbitol, valeric acid, potassium 2-ketogluconate or 4-hydroxybenzoic acid (API 20NE and API ID 32GN test strips). Positive for the following enzyme activities: $\beta$-galactosidase, alkaline

Table 2. Fatty acid compositions of strain $J S 12-13^{\top}$ and type strains of recognized Polaromonas species

Strains: 1 JS12-13 ${ }^{\mathrm{T}} ; 2$, P. aquatica CIP $108776^{\mathrm{T}} ; 3$, P. hydrogenivorans DSM $17735^{\mathrm{T}}$; 4, P. naphthalenivorans DSM $15660^{\mathrm{T}}$; 5, P. vacuolata $34-$ $\mathrm{P}^{\mathrm{T}}$ (data from Kämpfer et al., 2006). Cells of strains JS12-13 ${ }^{\mathrm{T}}$, KACC $11696^{\mathrm{T}}$ and DSM $15660^{\mathrm{T}}$ were harvested after growth on R2A agar at $28{ }^{\circ} \mathrm{C}$ for 3 days. Strain DSM $17735^{\mathrm{T}}$ was grown on R2A agar at $10{ }^{\circ} \mathrm{C}$ for 4 days. Only fatty acids that represent more than $0.5 \%$ of the total fatty acids are indicated.

\begin{tabular}{|lrrrrc|}
\hline Fatty acid & $\mathbf{1}$ & $\mathbf{2}$ & $\mathbf{3}$ & $\mathbf{4}$ & $\mathbf{5}$ \\
\hline $\mathrm{C}_{8: 0} 3-\mathrm{OH}$ & 1.3 & 1.0 & 0.8 & 0.5 & 2.8 \\
$\mathrm{C}_{10: 0} 3-\mathrm{OH}$ & - & - & 3.1 & 3.5 & - \\
$\mathrm{C}_{12: 0}$ & 2.9 & - & - & - & - \\
$\mathrm{C}_{14: 0}$ & 0.6 & 0.6 & - & - & - \\
$\mathrm{C}_{15: 1} \omega 6 c$ & 0.9 & 0.6 & - & - & - \\
$\mathrm{C}_{16: 0}$ & 28.4 & 33.8 & 14.1 & 28.0 & 9.5 \\
$\mathrm{C}_{16: 1} \omega 5 c$ & 0.7 & 0.5 & 1.6 & 1.0 & - \\
$\mathrm{C}_{17: 0}$ & 0.8 & 1.0 & - & - & - \\
$\mathrm{C}_{17: 0}$ cyclo & 15.9 & 30.7 & - & 12.9 & 0.8 \\
$\mathrm{C}_{18: 0}$ & 0.7 & 0.5 & - & - & - \\
$\mathrm{C}_{18: 1} \omega 7 c$ & 9.1 & 7.2 & 5.2 & 3.1 & 7.5 \\
$\mathrm{C}_{18: 1} \omega 7 c$ 11-methyl & - & - & - & - & 4.5 \\
Summed features & & & & & \\
$3^{*}$ & 38.3 & 23.4 & 75.2 & 49.1 & 73.7 \\
$7 \dagger$ & - & - & - & 2.0 & - \\
\hline
\end{tabular}

* Summed feature 3 comprises $\mathrm{C}_{16: 1} \omega 7 c$ and/or iso- $\mathrm{C}_{15: 0} 2-\mathrm{OH}$. $\dagger$ Summed feature 7 comprises $\mathrm{C}_{19: 1} \omega 6 c, \mathrm{C}_{17: 0}$ cyclo and/or an unknown fatty acid with an equivalent chain length of 18.846 . 
phosphatase, esterase (C4), esterase lipase (C8), leucine arylamidase and acid phosphatase (API 20NE and API ZYM). Negative for the following characteristics: nitrate reduction, indole production, glucose fermentation, arginine dihydrolase, urease, aesculin hydrolysis, gelatin hydrolysis, lipase (C14), valine arylamidase, cystine arylamidase, trypsin, $\alpha$-chymotrypsin, $\alpha$-galactosidase, $\beta$ glucuronidase, $\alpha$-glucosidase, $\beta$-glucosidase, $N$-acetyl- $\beta$ glucosaminidase, $\alpha$-mannosidase and $\alpha$-fucosidase (API 20NE and API ZYM). Naphthol-AS-BI-phosphohydrolase activity is weak (API ZYM). The predominant fatty acids are summed feature $3, \mathrm{C}_{16: 0}$ and $\mathrm{C}_{17: 0}$ cyclo. The major quinone is ubiquinone-8. The DNA $\mathrm{G}+\mathrm{C}$ content of the type strain is $63.7 \mathrm{~mol} \%$.

The type strain, JS12-13 ${ }^{\mathrm{T}} \quad\left(=\mathrm{KACC} 12508^{\mathrm{T}}=\mathrm{DSM}\right.$ $19351^{\mathrm{T}}$ ), was isolated from a soil sample collected from Halla Mountain on Jeju Island, Republic of Korea.

\section{Acknowledgements}

This work was supported by a grant (06-4-11-19-1) from the National Institute of Agricultural Biotechnology, Rural Development Administration, Republic of Korea.

\section{References}

Fitch, W. M. (1971). Toward defining the course of evolution: minimum change for a specific tree topology. Syst Zool 20, 406-416.

Groth, I., Schumann, P., Weiss, N., Martin, K. \& Rainey, F. A. (1996). Agrococcus jenensis gen. nov., sp. nov., a new genus of actinomycetes with diaminobutyric acid in the cell wall. Int J Syst Bacteriol 46, 234-239.

Irgens, R. L., Gosink, J. J. \& Staley, J. T. (1996). Polaromonas vacuolata gen. nov., sp. nov., a psychrophilic, marine, gas vacuolate bacterium from Antarctica. Int J Syst Bacteriol 46, 822-826.

Jeon, C. O., Park, W., Ghiorse, W. C. \& Madsen, E. L. (2004). Polaromonas naphthalenivorans sp. nov., a naphthalene-degrading bacterium from naphthalene-contaminated sediment. Int J Syst Evol Microbiol 54, 93-97.

Kämpfer, P., Busse, H.-J. \& Falsen, E. (2006). Polaromonas aquatica sp. nov., isolated from tap water. Int J Syst Evol Microbiol 56, 605-608.

Kumar, S., Tamura, K. \& Nei, M. (2004). MEGA3: integrated software for molecular evolutionary genetics analysis and sequence alignment. Brief Bioinform 5, 150-163.

Kwon, S. W., Kim, J. S., Park, I. C., Yoon, S. H., Park, D. H., Lim, C. K. \& Go, S. J. (2003). Pseudomonas koreensis sp. nov., Pseudomonas umsongensis sp. nov. and Pseudomonas jinjuensis sp. nov., novel species from farm soils in Korea. Int J Syst Evol Microbiol 53, 21-27.

Mesbah, M., Premachandran, U. \& Whitman, W. B. (1989). Precise measurement of the $\mathrm{G}+\mathrm{C}$ content of deoxyribonucleic acid by highperformance liquid chromatography. Int J Syst Bacteriol 39, 159-167.

Reasoner, D. J. \& Geldreich, E. E. (1985). A new medium for the enumeration and subculture of bacteria from potable water. Appl Environ Microbiol 49, 1-7.

Saitou, N. \& Nei, M. (1987). The neighbor-joining method: a new method for reconstructing phylogenetic trees. Mol Biol Evol 4, 406-425.

Seldin, L. \& Dubnau, D. (1985). Deoxyribonucleic acid homology among Bacillus polymyxa, Bacillus macerans, Bacillus azotofixans, and other nitrogen-fixing Bacillus strains. Int J Syst Bacteriol 35, 151-154.

Sizova, M. \& Panikov, N. (2007). Polaromonas hydrogenivorans sp. nov., a psychrotolerant hydrogen-oxidizing bacterium from Alaskan soil. Int J Syst Evol Microbiol 57, 616-619.

Smibert, R. M. \& Krieg, N. R. (1994). Phenotypic characterization. In Methods for General and Molecular Bacteriology, pp. 607-654. Edited by P. Gerhardt, R. G. E. Murray, W. A. Wood \& N. R. Krieg. Washington, DC: American Society for Microbiology.

Stackebrandt, E. \& Goebel, B. M. (1994). Taxonomic note: a place for DNA-DNA reassociation and 16S rRNA sequence analysis in the present species definition in bacteriology. Int J Syst Bacteriol 44, 846-849.

Thompson, J. D., Higgins, D. G. \& Gibson, T. J. (1994). CLUSTAL W: improving the sensitivity of progressive multiple sequence alignment through sequence weighting, position-specific gap penalties and weight matrix choice. Nucleic Acids Res 22, 4673-4680. 